\title{
Aplikasi Monitoring Aset dan Inventaris Laboratorium Berbasis Web Pada Kampus Politeknik Negeri Ujung Pandang
}

\author{
Mardawia Mabe Parenreng ${ }^{1, a}$ dan Mardhiyah Nas ${ }^{2, b}$ \\ 1,2 Jurusan Teknik Elektro, Politeknik Negeri Ujung Pandang, Jl. Perintis Kemerdekaan Km. 10, Makassar 90234 \\ ${ }^{a}$ mmparenreng@poliupg.ac.id \\ b mardhiyahnas@poliupg.ac.id
}

Abstract - Polytechnic is a university that organizes vocational education in various science and technology clusters. The learning process in polytechnic is dominated by practicum that is $70 \%$ and $30 \%$ theory. The amount of laboratory percentage affects the large number of laboratory. Each laboratory has a laboratory responsible (technician) in charge of recording and monitoring the completeness and condition of the practicum equipment. Tools and materials used in the process of practicum is an asset and laboratory inventory that must always be maintained and checked the condition of the equipment. In Ujung Pandang State Polytechnic (PNUP) in terms of asset monitoring and practicum inventory is still done manually. Therefore need to make an application to monitor assets and laboratory inventory, especially on campus two. It is known that since 2014 there are three departments that have implemented the teaching and learning process in two campuses including several laboratories have also been transferred to the two campuses, such as electrical engineering majors, majoring in business administration and accounting majors. So with this application will greatly help technicians because no longer do the reporting or request tool manually and with this application in monitoring the condition of the tool is damaged and tools that need further improvement more easily and can be quickly updated. The creation of this system begins with the needs analysis, design design as the basis of system development, the right of access consists of technicians of each laboratory and procurement department on campus one, content creation consists of laboratory data, checking tools and materials, repair tools and materials and demand tools and materials then print data laboratory

\section{Keywords: Information System; Web; Monitoring;} Laboratory.

Abstrak - Politeknik merupakan perguruan tinggi yang menyelenggarakan pendidikan vokasi dalam berbagai rumpun ilmu pengetahuan dan teknologi. Proses pembelajaran di politeknik didominasi oleh praktikum yaitu $70 \%$ dan teori $30 \%$. Besarnya persentase praktikum berpengaruh pada banyaknya jumlah laboratorium. Setiap laboratorium memiliki penanggung jawab laboratorium (teknisi) yang bertugas mendata dan memantau kelengkapan dan kondisi peralatan praktikum. Alat dan bahan yang digunakan dalam proses praktikum merupakan aset dan inventaris laboratorium yang harus selalu dijaga dan dicek kondisi peralatannya. Di Politeknik Negeri Ujung Pandang (PNUP) dalam hal monitoring aset dan inventaris praktikum masih dilakukan secara manual. Maka dari itu perlu dibuat sebuah aplikasi untuk memonitoring aset dan inventaris laboratorium khususnya pada kampus dua. Diketahui bahwa sejak 2014 ada tiga jurusan yang telah melaksanakan proses belajar mengajar dikampus dua termasuk beberapa laboratoriun juga sudah dipindahkan kekampus dua, antara lain yaitu jurusan teknik elektro, jurusan administrasi bisnis dan jurusan akuntansi. Sehingga dengan aplikasi ini akan sangat membantu teknisi karena tidak lagi melakukan pelaporan ataupun permintaan alat secara manual serta dengan aplikasi ini dalam memonitoring kondisi alat yang rusak dan alat yang perlu perbaikan lanjut lebih mudah dan dapat dengan cepat diupdate.Pembuatan sistem ini dimulai dengan melakukan analisi kebutuhan, perancangan desain sebagai dasar pembuatan sistem, hak akses terdiri dari teknisi masing-masing lab dan bagian pengadaan pada kampus satu, pembuatan content terdiri dari data lab, pengecekan alat dan bahan, perbaikan alat dan bahan serta permintaan alat dan bahan selanjutnya cetak data lab.

Kata Kunci: Sistem Informasi; Web; Monitoring; Laboratorium.

\section{Pendahuluan}

Politeknik merupakan perguruan tinggi yang menyelenggarakan pendidikan vokasi dalam berbagai rumpun ilmu Pengetahuan dan/ atau Teknologi dan jika memenuhi syarat, politeknik dapat menyelenggarakan pendidikan profesi [1]. Proses pembelajaran di politeknik didominasi praktikum dengan persentasi $70 \%$ dan 30\% teori, hal ini bertujuan menyiapkan mahasiswa menjadi anggota masyarakat yang memiliki kemampuan profesional yang dapat menerapkan, mengembangkan 
dan menyebarluaskan ilmu pengetahuan dan teknologi untuk meningkatkan kesejahteraan hidup masyarakat.

Besarnya persentasi praktikum tentu saja mempengaruhi jumlah laboratorium yang ada di politeknik. Setiap laboratorium memiliki penanggung jawab laboratorium (teknisi) yang bertugas untuk mendata dan memantau kelengkapan dan kondisi peralatan praktikum. Alat dan bahan yang digunakan dalam proses parktikum merupakan aset dan inventaris laboratorium yang harus dijaga dan dicek kondisi peralatannya, misal untuk jurusan teknik elektro, pada praktikum pengukuran, dibutuhkan alat dan bahan seperti resistor, dioda, multimeter, kabel konektor dan lain-lain. Maka untuk memantau kondisi alat dan bahan ataupun kekurangannya maka teknisi akan mengecek kondisi peralatan setiap selesai digunakan oleh mahasiswa.

Jika ada alat atau bahan yang rusak maka teknisi bertugas mendata untuk selanjutnya dilaporkan kebagian pengadaan alat dan bahan. Selain itu, pengadaan peralatan praktikum rutin dilakukan setiap tahun ajaran baru. Setiap teknisi diminta untuk mendata alat dan bahan praktikum yang perlu ditambah untuk digunakan selama dua semester kedepan. Proses pendataan dilakukan secara manual yaitu bahan dan alat dicatat pada form permintaan alat, lalu diantarakan kekampus satu. Karena prosesnya masih manual, tidak jarang terjadi kesalahan dalam pendataan, sehingga yang terjadi kebutuhan untuk praktikum dua semester kedepan menjadi kurang dan terkadang kukurangan alat ini berdampak pada proses praktikum dikampus dan tidak jarang pula karena kekurangan alat, praktikum ditunda atau bahkan di-cancel.

Di Politeknik Negeri Ujung Pandang (PNUP) tidak jarang terjadi hal serupa yaitu kekurangan peralatan laboratorium hal ini disebabkan kurang baiknya pendataan pada bagian teknisi. Disamping itu saat ini PNUP memiliki dua kampus dimana jarak antara kampus satu dan kampus dua sekitar $7 \mathrm{~km}$. Diketahui bahwa sejak 2014 ada tiga jurusan yang telah melaksanakan proses belajar mengajar dikampus dua termasuk beberapa laboratoriun juga telah dipindahkan kekampus dua, antara lain yaitu jurusan teknik elektro, jurusan administrasi bisnis dan jurusan akuntansi. Jika kampus dua kekurangan alat atau bahan praktikum, maka teknisi mencatat segala kekurangan selanjutnya melaporkan ke penaggung jawab kampus dua, lalu diteruskan ke bagian pengadaan alat dan bahan yang berada di kampus satu. Kondisi ini tentunya terlalu berbelit-belit sehingga tidak efektif dan tidak efissien.
Berdasarkan kondisi diatas, maka perlu adanya sebuah aplikasi monitoring aset dan inventaris laboratorium. Hal ini dimaksudkan agar mempermudah kerja teknisi. Beberapa penelitian yang sejalan dengan kondisi dari PNUP yaitu [2] melakukan pengembangan sebuah system berbasis computer yang digunakan untuk mengelolah data peningkatan dan pemeliharaan transportasi, [3] penelitian system monitoring data asset dan inventaris PT. Telkom cianjur berbasis web, [4] membuat system informasi berbasis web pada perpustakaan SDN sukoharj pacitan, [5] system informasi terkait pegawai pada taman kanak-kanak.

Terakhir pada penelitian terkait sistem informasi berbasis web untuk inventaris laboratorium telah dibahas sebelunya [6]. Berdasarkan dari penelitian yang telah ada, maka diangkat penelitian Aplikasi monitoring asset dan inventaris laboratorium berbasisi web pada kampus politeknik negeri ujung pandang. Dari aplikasi ini tentunya memberikan kemudahan dalam memonitoring kondisi alat yang rusak dan alat yang perlu perbaikan lebih lanjut yaitu dengan menginputkan kabagian perbaikan serta untuk pengadaan rutin tahunan yaitu pada bagian permintaan alat dan bahan dan dapat langsung diketahui oleh bagian perbaikan ataupun pengadaan. Aplikasi ini akan terhubung langsung kebagian pengadaan peralatan dikampus PNUP. Sehingga dengan aplikasi ini teknisi tidak perlu lagi membuat pemohonan permintaan ataupun pengadaan alat dan bahan secara manual. Dengan aplikasi ini maka kerja teknisi mejadi efektif dan efisein.

\section{Metode Penelitian}

\section{A. Analisis Kebutuhan}

Pada tahapan ini dilakukan analisi kebutuhan akan pentingnya pengadaan sistem informasi untuk memonitoring aset dan inventaris pada setiap laboratorium yang ada dikampus dua politeknik negeri ujung pandang, mengingat selama ini sistem monitoring yang dilakukan masih konvensional/ manual.

\section{B. Tahapan Penelitian}

Tahapan-tahapan penelitian ini secara garis besar dijelaskan pada gambar 1 berikut: 


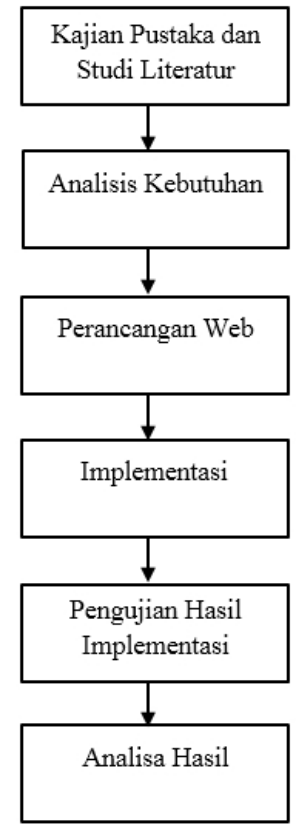

Gambar 1. Tahapan-tahapan Penelitian

\section{Perancangan Web}

Tahapan perancangan web dilakukan dengan menentukan bagian penting yang harus ada dalam aplikasi web, yaitu:

1. Hak akses, merupakan bagian utama dari sebuah aplikasi karena yang akan menggunakan mengatur dan mengontrol aplikasi tergantung hak akses yang diberi. Pada aplikasi monitoring aset dan inventaris laboratotium hak akses dibagi menjadi dua yaitu hak akses pada bagian pengadaan dan hak akses bagi teknisi. Dimana admin akan membuat akun bagi untuk teknisi dan bagian pengadaan. Akun ini nantinya yang akan digunakan untuk mengakses web aset dan inventaris laboratorium. Admin berhak menghapus akun teknisi jika ada pergantian teknisi

2. Content, merupakan bagian yang digunakan oleh user ketika mengakses aplikasi. Aplikasi monitoring aset dan inventaris laboratorium memiliki beberapa content diantaranya data lab, Pengecekan alat dan bahan, perbaikan alat dan bahan, permintaan alat dan bahan.

3. Front end, merupakan tampilan interface yang dapat dilihat dan mudah dalam pengoperasian, serta akan beroperasi berdasarkan sistem yang dirancang. Sekarang ini front end telah banyak dikembangkan dan lebih memudahkan pengguna untuk mengakses content-content aplikasi.
4. Back end, merupakan suatu program dan script yang bekerja pada server dibalik layar untuk membuat halaman web yang dinamis dan interaktif. Adapun proses yang umumnya berlangsung pada back end adalah:

a. Desain informasi, berkaitan dengan bagaimana suatu informasi diatur di server

b. Perosesan form

c. Pemrograman database

d. Manajemen content

e. Aplikasi berbasis web serverb lain menggunakan PHP

\section{Implementasi}

Hasil perancangan pada tahapan sebelumnya akan diimplementasikan pada tahapan ini. Desain awal yaitu pada home page berisi content yang telah dijelaskan pada bagian perancangan web, selanjutnya setiap content akan berisi sub-content misalnya data laboratorium berisi semua jurusan yang ada dikampus dua, laboratorium dan bengkel yang ada kampus dua beserta alat dan bahan pada setiap laboratorium dan bengkel. Pengecekan alat dan bahan, berisi total alat dan bahan, kondisi alat atau bahan yang rusak dan bagus pada masing-masing laboratorium, untuk selanjutnya pada perbaikan berisi alat dan bahan yang rusak dan diajukan kebagian maintenance dan repair (MR) untuk dilakukan perbaikan. Permintaan berisi permintaan alat dan bahan yang dibutuhkan di masing-masing laboratorium untuk kebutuhan praktikum selama dua semester.

\section{Hasil dan Pembahasan}

Berikut ini hasil yang telah diperoleh dari aplikasi monitoring aset dan inventaris laboratorium berbasis web pada kampus politeknik negeri ujung pandang dengan fokus penelitian pada kampus dua. Pada web ini terdapat admin yang bertugas untuk mengontrol siapa saja yang berhak mengakses web inventris ini. Admin berhak untuk menghapus akun yang telah terdaftar sebelumnya, mengedit ataupun menambahkan akun jika terjadi perubahan. Hal ini dimaksudkan untuk keamanan aset dan inventaris dari kampus dan menghindari terjadinya hilangnya data yang berkaitan dengan aset dan inventaris kampus. 


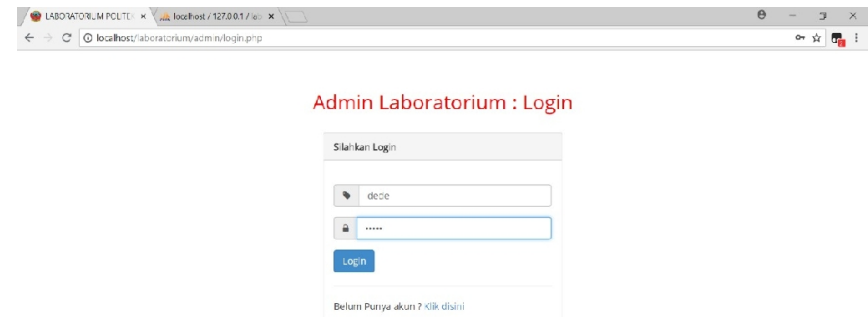

\section{=}

Gambar 1. Halaman Login Admin Laboratorium

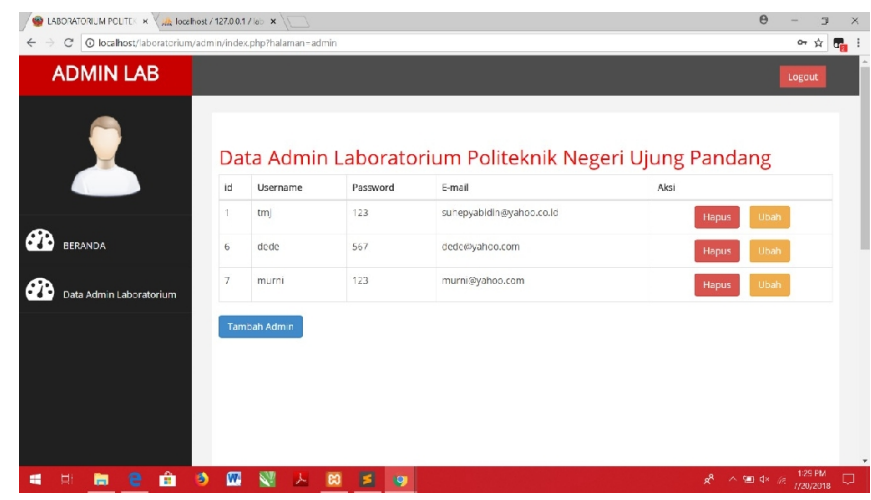

Gambar 2. Halaman Data Admin Laboratorium PNUP

Gambar 1 menunjuknya login untuk admin, dan gambar 2 menunjukkan akun yang telah terdaftar. Hak akses diberikan kepada teknisi masing-masing laboratorium untuk setiap jurusan yang ada di kampus dua pnup dan juga hak akses pada bagian pengadaan.

Setalah akun masing-masing teknisi telah didaftar, selanjutnya teknisi dapat mengakses web aset dan inventaris dengan tampilan login seperti gambar 3 . Setelah dilakukan login, maka masuk ke halaman pertama web seperti gambar 4 .

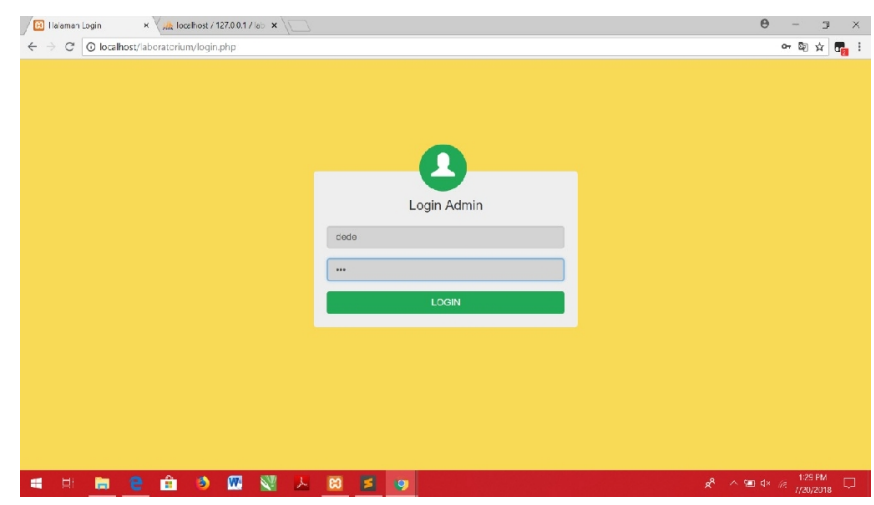

Gambar 3. Halaman Login Teknisi Laboratorium

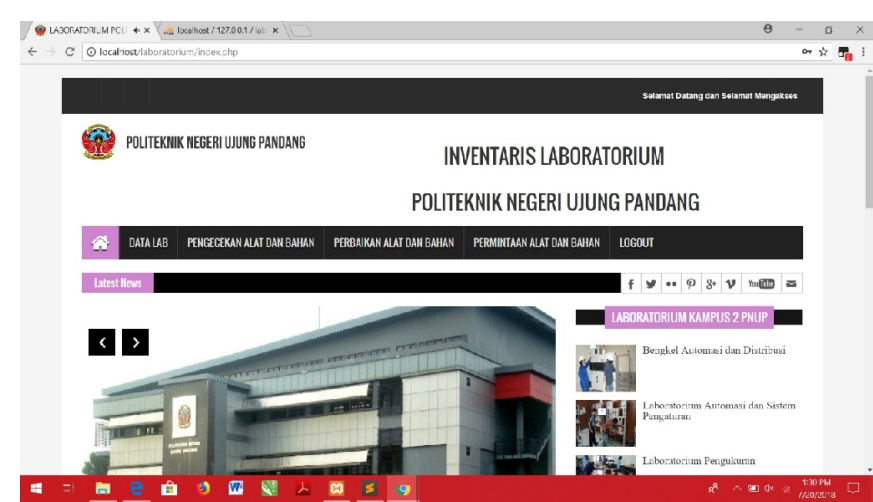

Gambar 4. Halaman Beranda

Setelah masuk halaman web inventaris laboratorium, teknisi memiiki hak untuk melakukan input data laboratorium, mengedit ataupun menghapus data yang tidak dibutuhkan lagi. Pada gambar 5 terlihat jurusanjurusan yang ada di kampus dua, terdiri dari jurusan teknik elektro, jurusn administrasi niaga dan jurusan akuntansi. Kemudian dilakukan simulasi dengan meninputkan data laboratorium untuk jurusan teknik elektro program studi teknik multimedia dan jaringan, pada lab. Multimedia, seperti terlihat pada gambar 6. Pada halaman ini tampian berupa tabel data barang dan bahan laboratorium dan setalah dilakukan penginputan dapat langsung dicetak, seperti pada gambar 7

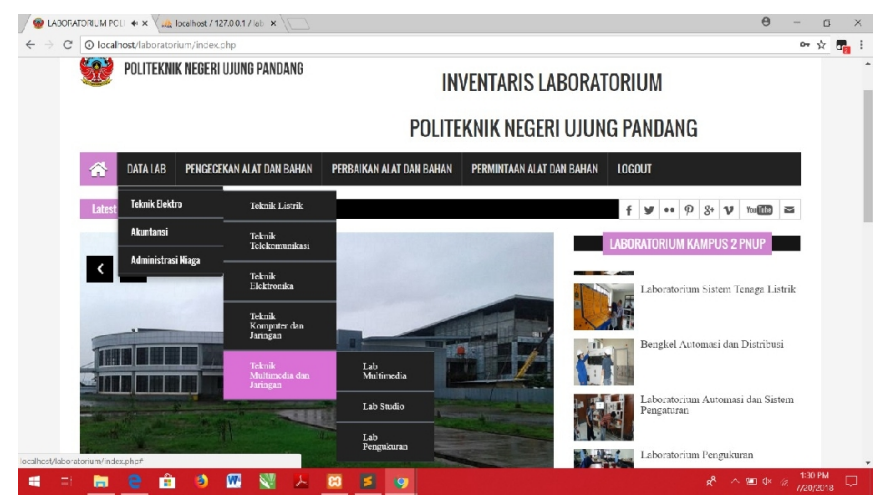

Gambar 5. Menu dan Submenu Data Laboratorium

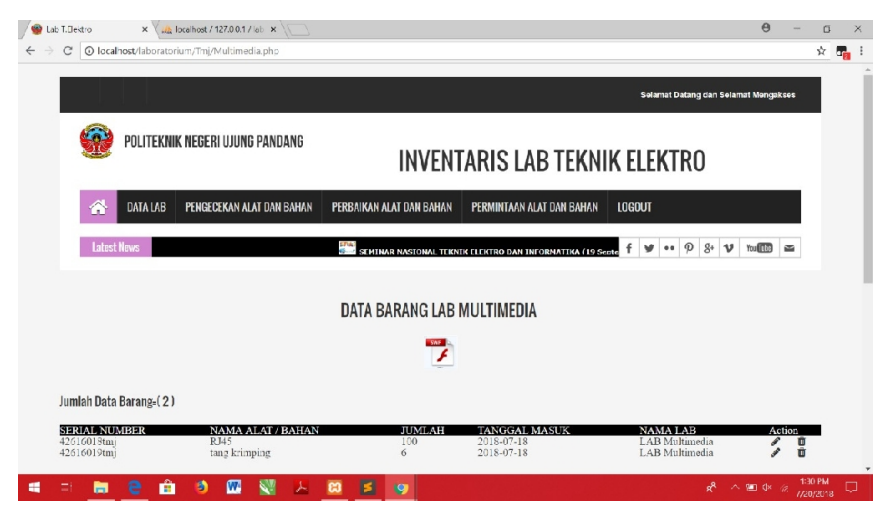

Gambar 6. Halaman Data Barang Lab Multimedia 


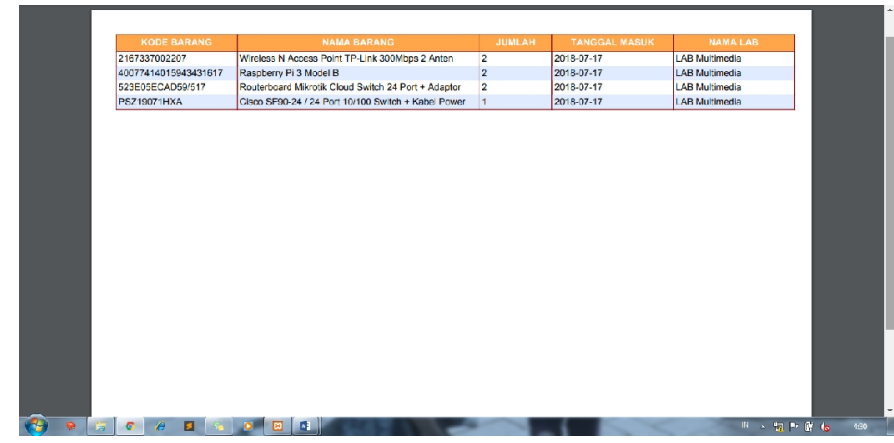

Gambar 7. Hasil Cetak Data Laboratorium

Pada gambar 8 menampilkan menu permintaan alat dan bahan. Pada bagian ini berisi daftar permintaan alat dan bahan yang akan diajukan untuk digunakan pada proses perkuliahan satu semester kedepan. Selanjutnya pada gambar 9 tampilan untuk inputan permintaan.

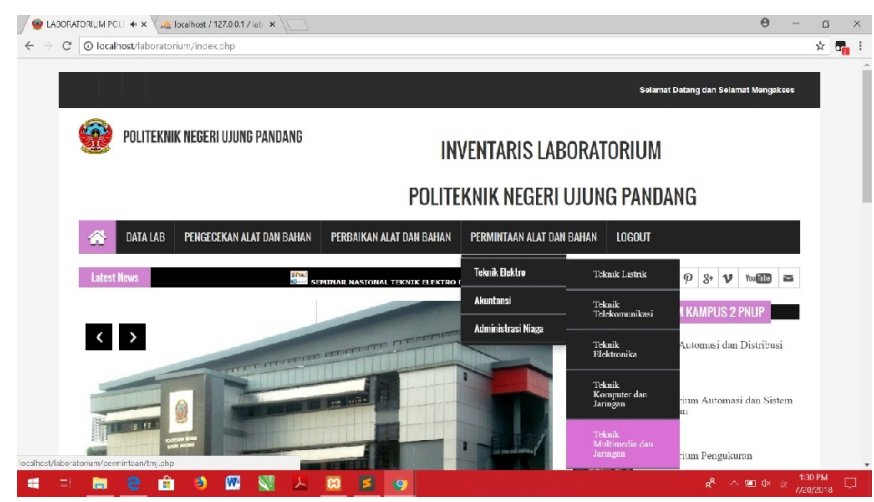

Gambar 8. Menu dan Submenu Permintaan Alat / Bahan

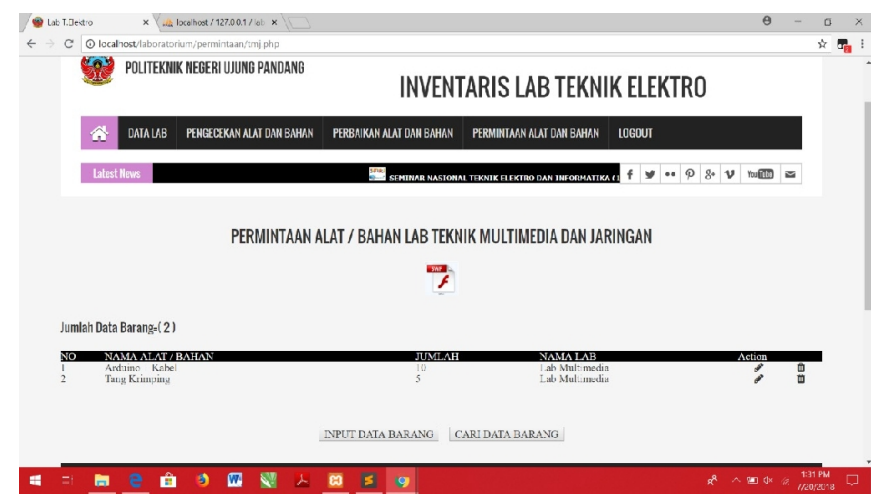

Gambar 9. Halaman Permintaan Alat / Bahan Teknik Multimedia dan Jaringan

\section{Kesimpulan}

Aplikasi monitoring aset dan inventaris laboratorium berbasis web pada kampus politeknik negeri ujung pandang, merupakan aplikasi diperuntukkan untuk teknisi laboratorium pada setiap jurusan yang berada dikampus dua politeknik negeri ujung pandang, dengan aplikasi ini nantinya masing-masing dari teknisi laboratorium tidak perlu lagi melakukan pelaporan kerusakan laboratorium ataupun pengadaan alat dan bahan secara manual cukup dengan mengakses web inventaris laboratorium sehingga kerja teknisi menjadi lebih ringan dan dari efisiensi bisa lebih efisien dari segi waktu ataupun penggunaan kertas. Sebagai saran untuk pengembangan penelitian ini, dapat dikembangkan dengan membuat sistem aset dan inventaris laboratorium menggunakan android yang diinstal pada smart phone, sehingga lebih memudahkan untuk diakses.

\section{Ucapan Terima Kasih}

Ucapan terima kasih diberikan kepada Kementrian Riset dan Teknologi DIKTI yang telah membiayai penelitian ini, dan Politeknik Negeri Ujung Pandang, Jurusan Teknik Elektro Program Studi Teknik Multimedia dan Jaringan yang telah memberikan fasilitas laboratorium sebagai tempat pengerjaan penelitian ini, serta semua yang terlibat dalam penelitian ini.

\section{Daftar Pustaka}

[1] Undang-undang Republik Indonesia No.12.2012, Tentang Pendidikan Tinggi. Jakarta.

[2] Mudjahidin, N. D. Pahang Putra, "Rancang Bangun Sistem Informasi Monitoring Perkembanga Proyek berbasis Web Studi Kasus di Dinas Bina Marga dan Pemantusan," Institut Teknologi Sepuluh November Surabaya: Surabaya, 2010

[3] G. Tri Mradiani, "Sistem Monitoring Data Aset dan Inventaris PT. Telkom Cianjut Berbasis Web," Universitas Komputer Indonesia: Bandung, 2013

[4] F. Hariadi, "Pembuatan Sistem Informasi Perpustakaan Pada SDN sukoharjo Pacitan Berbasis Web," Indonesia Journal on Networking and Security-ISSN 2302-5700, 2013.

[5] T. Purnamasari, "Pembangunan Sistem Informasi Data Pegawai dan Penggajian Pada Unit Pelaksana Teknis Taman Kanakkanak dan Sekolah Dasar Kecamatan Pringkuku," Journal Speed-Sentra Penelitian Engineering dan Edukasi-Volume 5 No. 2, 2013

[6] H. Wahid Luthfi, B. Kusuma Riasti, "Sistem Informasi Perawatan dan Inventaris Laboratoriumoratoriumoratorium pada SMK Negeri 1 Rembang Berbasis Web," Journal SpeedSentra Penelitian Engineering dan Edukasi-Volume 5 No.2, 2011 